\title{
Students' Perception on Teaching Performances of Trained Teachers focusing undergraduate lecture classes in Bangladesh
}

\author{
Dr. Shamima Parvin ${ }^{l}$, Brigadier General Md. Ahsan Habib ${ }^{2}$, Prof. Md. Humayun Kabir Talukder ${ }^{3}$, Dr. Rukshana Ahmed ${ }^{4}$
}

\begin{abstract}
Background: Teachers' training is a kind of education that helps the teachers to understand the basic theories of teachinglearning for escalating their knowledge, skills and abilities according to the learner's need.

Objectives: The present study was undertaken to identify the students' perception about the teaching performances of the teachers who had gone through the training on teaching methodology at Centre for Medical Education(CME) in Bangladesh.

Methods: This descriptive type of cross sectional study was conducted in thirteen public and private medical colleges of Bangladesh. A structured questionnaire based on 5-point Likert scale was used to collect the students' perceptions which included 13 separate positive statements regarding classroom performances. Statements having mean score of 4 or more are considered as positive aspect of performance. Statements with mean score 3 or less indicate the problem area of performance. Statement with a mean score in-between 3 and 4 might be emphasized for further improvement.

Results: According to students' aggregated view, $38 \%$ of the teaching performances were excellent, $43 \%$ were good, $16 \%$ were satisfactory and $3 \%$ were unsatisfactory.

Conclusion: To ensure excellence in all aspects of teaching performances a well-designed, updated and contextual training programme needs to be adopted for further improvement of teaching-learning.
\end{abstract}

Key Words: Teaching performances, Trained teachers, CME, Students' perception, Lecture.

\section{Introduction}

There are good reasons to doubt the very popular belief that the teachers are born, not made. Basically several studies have shown that teaching is a learnable skill not an inherent quality. It is now general agreement that the medical teachers are not just a subject's expert, they also need some basic educational competencies in facilitating the learning of those subjects. Only few individuals acquire the competencies naturally, for others it must be developed by systematic teacher's training programme ${ }^{1,2}$. Teaching in a medical school has been acknowledged as an independent skill only in the second half of the 20th century. As a result teacher training programmes started in late 1970s and the 1980s. At that time medical schools started to train their teachers through short workshops, seminars and microteaching techniques ${ }^{3}$. The educational system has encountered massive transformation over the last few decades. The traditional concept of injecting knowledge to

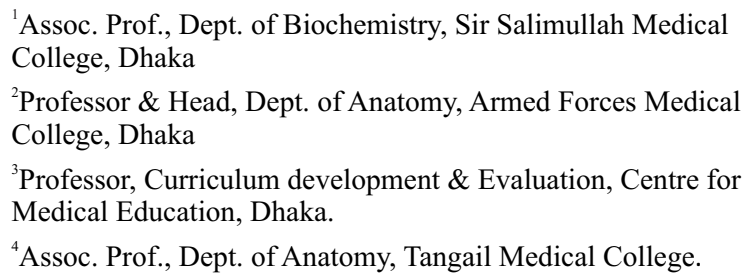

${ }^{4}$ Assoc. Prof., Dept. of Anatomy, Tangail Medical College.

Address of correspondence: Dr. Shamima Parvin

Assoc. Prof., Dept. of Biochemistry, Sir Salimullah Medical

College, Dhaka.

E mail: drs_kabir@yahoo.com, Cell: +88-01759911151 the learners has changed now; rather the main purpose of teaching is to facilitate learning effectively for building selfdirected learners. Formal training for teachers has been a routine in many medical schools. In 1996, University of Illinois at Chicago developed programmes to improve teaching skills of junior faculty. Effective teaching techniques are now a requirement for doctors and can be learnt and perfected like any other medical skill. Every doctor is expected to deliver teaching, whether to medical students, allied health professionals or post graduate doctors $^{4,5,6 .}$ We want the teacher should be a facilitator for developing active learning habit by the students. For that there is a need of well-trained teachers who will ultimately help to produce quality physicians. Therefore, regular teachers' training is emphasized globally and different types of workshops are planned for the medical teachers to encourage their attitude towards students-centered medical education ${ }^{7}$. For keeping the teachers of medical colleges up-to-date about the current practices of teaching methodology around the globe, Centre for Medical Education (CME) of Bangladesh has been organising the teaching methodology workshop ${ }^{8}$. But till date we do not know how much extent the teachers are practicing their acquired knowledge in their classroom activities. Students' perception about teaching performance could be an excellent source of information, as they are the direct consumers and their evaluation will help to determines whether the teacher is performing according to specified standard or not. As we know in our curriculum (MBBS curriculum 2012) major part of teaching-learning hours are

Bangladesh Journal of Medical Education 2016;7(1):14-19. (C) 2016 Parvin et al., publisher and licensee Association for Medical Education. This is an Open Access article which permits unrestricted non-commercial use, provided the original work is properly cited. 
occupied by lecture classes for all phases. That is why the present study was carried out to identify students' perception on the teaching performances of the trained teachers focusing their lecture classes. By this study, researcher tried to find out the strengths and weaknesses of the current classroom performances in the lecture classes of the trained teacher. The identified problem area of performances by the present study might be address during planning of the subsequent teaching methodology training.

\section{Methodology}

This descriptive type of cross sectional study was conducted in thirteen public and private medical colleges of Bangladesh after getting written permission from the principal of the respective medical colleges. Voluntary participation of the students was ensured and the names of the students' as well as teachers are kept confidential. The students who attended the lecture classes conducted by the trained teachers were the study population; among them one thousand and two hundred (1200) students were taken as sample by convenient sampling. Data collection instrument was a structured questionnaire which was developed on the basis of "Dundee Ready Education Environment Measure (DREEM)" inventories and literature review to collect the students' perceptions that included 13 separate positive statements. Each statement was followed by 5-point Likert scale with maximum score 5 and minimum score1. Statements having mean score of 4 or more are considered as positive aspect of the performance. Any statement with mean score 3 or less should be considered carefully as they indicate the problem area of performance. Statement with a mean score in-between 3 and 4 might be emphasized for further improvement of performance. The data collection instruments were pretested in one of the lectures classes and were refined as per feedback of the respondents. Researcher had given a short briefing to the student explaining the procedure to be followed during filling out of the questionnaire just before the beginning of a class then it was given to all attending students just after completion of each class and allowed 10 minutes time for putting a tick marks in a right place according to their own choice. After completion of data collection, the questionnaire used for collecting students' perception about the lecture classes was serially numbered from 1-1200. All the tick marked score from the questionnaire was entered in Excel sheet of computer according to the prior serial number. A worksheet was made in Microsoft Excel sheet to count the view of the students. Calculated values were transferred to SPSS version 19 for analysis. Classification, tabulation, graphical presentation and measurement of central tendency of the values were done.

\section{Results}

\section{Students' view on teaching performances}

Table I shows the frequency distribution with mean $( \pm \mathrm{SD})$ score. In this study out of 1200 students, $67.8 \%$ of them showed satisfaction regarding classroom settings. About $72 \%$ of the students agreed that the teachers had successfully drawn their attention and $75 \%$ were well informed about the learning objectives of the session. Around $65 \%$ of the students agreed that the teachers had assessed their preceding knowledge and $71.6 \%$ agreed that lectures were well organized and sequential. About $66 \%$ the students agreed about proper guidance for understanding of the topic and $72.4 \%$ students viewed that teachers competently used the audiovisual aids. Majority of the students $(56.6 \%)$ showed their agreement about the maintenance of eye contact with them and $75 \%$ of the students agreed that the voice of the teachers was very clear and audible. Approximately $65 \%$ of the students satisfied about required feedback from the teachers and $65 \%$ of the students agreed that class topic was completed as per learning objectives. Sixty percent of the students agreed about good summarisation of the session and $57.1 \%$ students viewed that they received necessary guideline from the class for their self-learning.

Table-I: Frequency distribution with central tendency of teaching performances focusing on lecture classes as per students' view $(\mathrm{n}=1010)$.

\begin{tabular}{|l|c|c|c|c|c|c|}
\hline \multicolumn{1}{|c|}{ Statements about the teaching performances } & \multicolumn{6}{|c|}{ Student's view } \\
\cline { 2 - 7 } & $\begin{array}{c}\text { SA } \\
\mathbf{f}(\%)\end{array}$ & $\begin{array}{c}\mathbf{A} \\
\mathbf{f}(\%)\end{array}$ & $\begin{array}{c}\text { UC } \\
\mathbf{f}(\%)\end{array}$ & $\begin{array}{c}\text { DA } \\
\mathbf{f}(\%)\end{array}$ & $\begin{array}{c}\text { SDA } \\
\mathbf{f}(\%)\end{array}$ & $\begin{array}{c}\text { Score } \\
\text { Mean } \pm \text { SD }\end{array}$ \\
\hline Classroom settings were comfortable & 237 & 449 & 129 & 134 & 61 & $3.36 \pm 1.15$ \\
& $(23.4)$ & $(44.4)$ & $(12.7)$ & $(13.2)$ & $(6.0)$ & \\
\hline Attention was drawn at the starting of a class & 337 & 390 & 141 & 87 & 55 & $3.86 \pm 1.13$ \\
& $(33.4)$ & $(38.6)$ & $(14.0)$ & $(8.6)$ & $(5.4)$ & \\
\hline Learning objectives were clearly stated & 332 & 425 & 114 & 85 & 54 & $3.89 \pm 1.11$ \\
& $(32.9)$ & $(42.1)$ & $(11.3)$ & $(8.4)$ & $(5.3)$ & \\
\hline Prior knowledge was assessed by teachers & 306 & 349 & 160 & 136 & 59 & $3.70 \pm 1.19$ \\
& $(30.3)$ & $(34.6)$ & $(15.8)$ & $(13.5)$ & $(5.8)$ & \\
\hline Presentation was well organised \& sequential & 284 & 439 & 168 & 80 & 39 & $3.84 \pm 1.04$ \\
\hline
\end{tabular}

Bangladesh Journal of Medical Education 2016;7(1):14-19. 


\begin{tabular}{|c|c|c|c|c|c|c|}
\hline \multirow[t]{2}{*}{ Statements about the teaching performances } & \multicolumn{6}{|c|}{ Student's view } \\
\hline & $\begin{array}{c}\text { SA } \\
\mathbf{f}(\%)\end{array}$ & $\begin{array}{c}A \\
\mathbf{f}(\%)\end{array}$ & $\begin{array}{c}\mathrm{UC} \\
\mathrm{f}(\%)\end{array}$ & $\begin{array}{c}\text { DA } \\
\mathbf{f}(\%)\end{array}$ & $\begin{array}{l}\text { SDA } \\
\text { f (\%) }\end{array}$ & $\begin{array}{c}\text { Score } \\
\text { Mean } \pm \text { SD }\end{array}$ \\
\hline Learning guidance was provided by teachers & $\begin{array}{c}291 \\
(28.8)\end{array}$ & $\begin{array}{c}379 \\
(37.5)\end{array}$ & $\begin{array}{c}150 \\
(14.9)\end{array}$ & $\begin{array}{c}118 \\
(11.7)\end{array}$ & $\begin{array}{c}72 \\
(7.1)\end{array}$ & $3.69 \pm 1.20$ \\
\hline Teaching aids were used competently by teachers & $\begin{array}{c}306 \\
(30.3)\end{array}$ & $\begin{array}{c}425 \\
(42.1)\end{array}$ & $\begin{array}{c}169 \\
(16.7)\end{array}$ & $\begin{array}{c}78 \\
(7.7)\end{array}$ & $\begin{array}{c}32 \\
(3.2)\end{array}$ & $3.89 \pm 1.02$ \\
\hline Eye contact was maintained with us & $\begin{array}{c}199 \\
(19.7)\end{array}$ & $\begin{array}{c}373 \\
(36.9)\end{array}$ & $\begin{array}{c}241 \\
(23.9)\end{array}$ & $\begin{array}{c}134 \\
(13.3)\end{array}$ & $\begin{array}{c}63 \\
(6.2)\end{array}$ & $3.51 \pm 1.13$ \\
\hline Presentation was clear and audible to us & $\begin{array}{c}311 \\
(30.8)\end{array}$ & $\begin{array}{c}450 \\
(44.6)\end{array}$ & $\begin{array}{l}140 \\
(13.9)\end{array}$ & $\begin{array}{c}79 \\
(7.8)\end{array}$ & $\begin{array}{l}30 \\
(3)\end{array}$ & $3.92 \pm 1.01$ \\
\hline Constructive feedback was provided timely & $\begin{array}{l}303 \\
(30)\end{array}$ & $\begin{array}{c}373 \\
(36.9)\end{array}$ & $\begin{array}{l}156 \\
(15.4)\end{array}$ & $\begin{array}{c}125 \\
(12.4)\end{array}$ & $\begin{array}{c}53 \\
(5.5)\end{array}$ & $3.74 \pm 1.16$ \\
\hline Contents were covered within allocated time & $\begin{array}{c}213 \\
(21.1)\end{array}$ & $\begin{array}{c}438 \\
(43.4)\end{array}$ & $\begin{array}{c}203 \\
(20.1)\end{array}$ & $\begin{array}{c}116 \\
(11.5)\end{array}$ & $\begin{array}{l}40 \\
(4)\end{array}$ & $3.66 \pm 1.05$ \\
\hline Summarisation was done at the end & $\begin{array}{l}212 \\
(21)\end{array}$ & $\begin{array}{c}395 \\
(39.1)\end{array}$ & $\begin{array}{c}179 \\
(17.7)\end{array}$ & $\begin{array}{c}148 \\
(14.7)\end{array}$ & $\begin{array}{c}76 \\
(7.5)\end{array}$ & $3.51 \pm 1.19$ \\
\hline Classes guided me for selfdirected learning & $\begin{array}{c}209 \\
(20.7)\end{array}$ & $\begin{array}{c}368 \\
(36.4)\end{array}$ & $\begin{array}{c}200 \\
(19.8)\end{array}$ & $\begin{array}{c}153 \\
(15.1)\end{array}$ & $\begin{array}{c}80 \\
(7.9)\end{array}$ & $3.47 \pm 1.20$ \\
\hline $\begin{array}{c}\text { SA: Strongly Agree (score= } \\
\text { DA: Disagree (scor }\end{array}$ & ee $(\sec$ & $=4), \mathbf{U}$ & Uncerts & (scor & & \\
\hline
\end{tabular}

\section{Students' aggregated view on teaching performances} According to aggregated views of the students, $38 \%$ of the teaching performances were Excellent, $43 \%$ of the teaching performances were Good, $16 \%$ were Satisfactory and 3\% were Unsatisfactory.

Excellent $=$ if mean score is $>4=$ Maintained a required standard (standard was set arbitrarily by researcher)

Good $=$ if mean score is $>3$ but $=4=$ Some extent of efforts are needed to reach a required standard

Satisfactory $=$ if mean score $>2$ but $=3=$ Moderate extent of efforts are needed to reach a required standard.

Unsatisfactory $=i$ mean score is $=2=$ Significant extent of efforts are needed to reach a required standard.

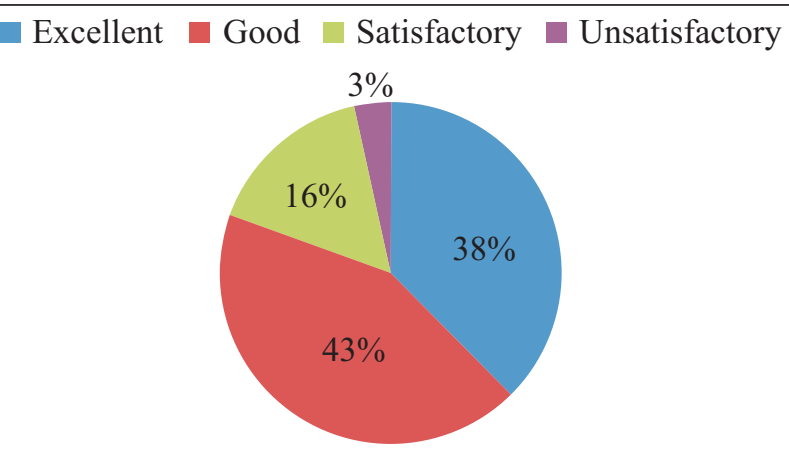

Figure-1: Student's aggregated view about the teaching performances focusing on lecture classes $(n=1200)$.

\section{Discussion}

Dent \& Harden ${ }^{9}$ mentioned that lectures are the oldest and most common method of learning in medicine and allied subjects but careful consideration needs to be given on how they are being delivered. Due to the usefulness and universal usages, it is important that all medical teachers should develop and refresh their expertise in lecturing. There were several studies on lecture evaluation both in Bangladesh and abroad. The present study tried to find out how much extent the trained teachers are practicing their learned competencies during conducting lecture classes according to the attending students' view.

The present study findings revealed that, $67.8 \%$ respondents showed positive agreement about classroom settings. Rahman ${ }^{10}$ conducted a cross-sectional study on assessing the role of medical teachers in lecture classes found that $59.2 \%$ of the students showed positive agreement towards comfortable classroom settings. Hutchinson ${ }^{11}$ said that teacher would have experienced the difficulties of running sessions in a cold or overheated room without sufficient lighting, in noisy rooms and absence of adequate seating arrangement. Physical factors can make it difficult for learners and teachers to relax and pay attention. These factors are considered as the physiological need according to Maslow's hierarchy needs for motivation. As we know from Hutchinson's citation and according to Maslow's law before starting a class, teachers have to ensure about classroom settings. The present study finding is consistent with their statement. Regarding drawing attention at the beginning of the class was a mean score of $3.86 \pm 1.13$.

Bangladesh Journal of Medical Education 2016;7(1):14-19. 
Rahman $^{10}$ in his study also found the similar result that $73 \%$ of teachers effectively gained attention. On the contrary, Mohammad et al. ${ }^{11}$ in her study observed that only $30.6 \%$ teachers gained attention successfully which was marked lower than the present study findings. Perhaps this variation maybe due to that all of the teachers in the present study have already trained on teaching methodology so we assumed they have gained knowledge about steps of Gagne's principle. About stating learning objectives of the session at the beginning of the class was a mean score of $3.89 \pm 1.11$; suggest that some extents of efforts are needed to reach a good standard. Study done by Nahar et al. ${ }^{13}$ that included 1903 MBBS students of 15 medical colleges in Bangladesh showed similar findings. Al-Naggar et al. ${ }^{14}$ conducted a study in Malaysia found a mean score of 3.53 for male and 3.72 for female which were also similar to this study findings. Yusoff et al. ${ }^{15}$ performed a study also in Malaysia and found a mean score of 3.80 from student's perception which support the findings of the present study as well. As cited by Guilbert ${ }^{16}$, Mager opined "If you are not certain of where you are going you may very well end-up somewhere else (and not even know it)". Amin and Eng ${ }^{17}$ indicated that learning objectives are short, well-structured statements that specify what the learners are expected to achieve at the end of a session. Most compelling reason for using objectives is to explain the intentions of the teachers to the learners that initiates the internal process of expectancy and motivates the learner to complete the lesson. Assessing prior knowledge related to the topic was a mean score of $3.70 \pm 1.20$. On this issue some extent of efforts are needed to reach a good standard. Rahman ${ }^{10}$ found that $65.4 \%$ students were agreed that teachers stimulated the prerequisite knowledge and $23 \%$ were towards disagreement which supports the finding of present study. Study of Gulpinar \& Yegen ${ }^{18}$ based on an interactive lecture found that only $13.3 \%$ students disagreed with the statement that during the presentation, prior knowledge was taken into consideration by the teachers. Study of Malik et al. ${ }^{19}$ was done on the science teachers and students of class $\mathrm{X}$ in three Govt. Boys High Schools in Pakistan found that $45 \%$ of the students disagreed with the statement "Teachers evaluate previous knowledge before the announcement of a new lesson", which was higher than the present study findings. About sequence of presentation, majority of the students $(71.6 \%)$ agreed that lectures were well organized and teachers had presented it sequentially. Rahman ${ }^{10}$ found that the most of the lectures $(53.3 \%)$ presented by the teachers were very well organised (very good-excellent). On the other hand, Mohammad ${ }^{11}$ found that only $41.7 \%$ were very well organised and $25 \%$ lectures were not at all organized. Both of the study result showed lower score than the present study indicates trained teachers had been trying to follow the steps of instructional models. Majority of the students $(66.3 \%)$ agreed that the teachers guided them properly for understanding the lesson by using suitable examples, related case / video / graphical presentation with a mean score of 3.69 \pm 1.20 ; but some extents of efforts are still needed to reach a desired standard. Sarker and Majumder ${ }^{20}$ in India had similar findings where majority of the students $(64.7 \%)$ approved that suitable example were quoted during lecture class. Murtaza et al. ${ }^{21}$ in Pakistan found that $100 \%$ student opined that teachers explained the topic with proper example which was higher than the present study findings. Nahar et al. ${ }^{13}$ in Bangladesh found the mean score of students view was of 3.52 which was roughly similar to the findings of the present study. Mayya and Roff ${ }^{22}$ in India found a mean score of 2.36 for academic achiever and 2.33 for academic non-achiever respectively which also supports the findings of the present study. Regarding competency in using teaching-learning aids, majority of the students $(72.4 \%)$ agreed that the teachers competently used the audiovisual aids that were helpful, clear \& understandable to them with mean score $3.89 \pm 1.02$. A study done by Debasis $^{23}$ in India found that $45.98 \%$ of the students agreed and $50.57 \%$ strongly agreed that power point presentation with chalk \& talk as a combined, was the best teachinglearning method in undergraduate medical education. Bennal et al. ${ }^{24}$ cited that effective use of audio-visual aids during lecture classes can make the students actively participate in learning process. His study revealed that $76.12 \%$ of the students prefer lecturing of theory classes with mix of audio-visual aids which supports the finding of present study. Regarding maintenance of eye contact with the students, majority of the students $(56.6 \%)$ agreed that the teachers had maintained a consistent and homogenous eye contact with them. Rahman ${ }^{10}$ found that most of the students $(75.5 \%)$ were in range of agreement that the teachers' maintained sufficient eye contact in the lecture classes which is higher than the present study findings. findings. Mohammad et $\mathrm{al}^{11}$ had similar findings where $72.2 \%$ teachers maintained eye contact most of the time. This aspect of teaching performance could be enhanced and some extents of efforts are needed to reach a desired standard. Regarding clarity of presentation, $75.4 \%$ of the students agreed that during delivery of the lecture teachers used simple word with sufficient pause and it was very clear $\&$ quite audible to them. As because mean score of students view was $3.92 \pm 1.01$ and it was below 4 , there is still a room for further improvement. Rahman ${ }^{10}$ found that $90 \%$ of the teacher's voice was audible from the last bench. Mohammad et $\mathrm{al}^{11}$ found that $63.9 \%$ teacher's voice was audible all the time and their results support the present study. Providing feedback to the students, $66.9 \%$ of the student agreed that teacher asked question from time to time and gave necessary feedback on the answer timely. Rahman ${ }^{10}$ found that $66.7 \%$ of the students agreed that the teacher gave immediate response to the student's question which was supportive finding for the present study. About content coverage, $64.5 \%$ ) agreed that contents were covered within the allocated time as per objectives of the session with a mean score of $3.66 \pm 1.05$. Some extents of efforts are still needed to reach a desired standard as mean score is below 4 . Malik et al. ${ }^{19}$ in Pakistan found that $100 \%$ of the students agreed that teacher took class in time which was higher than present study but the study was done on students studying science subjects of class X in three Govt. Boys High

Bangladesh Journal of Medical Education 2016;7(1):14-19. 
Schools in, Pakistan. Regarding summarisation of the session, study findings revealed that $60 \%$ of the students were in line with the agreement that teachers summarized the session with highlighted key points. Rahman ${ }^{10}$ also found that $30 \%$ teachers were unsatisfactory in providing summary at the end of the lesson supports the findings of the study. Although Mohammad et al ${ }^{11}$ found that $50 \%$ teachers did not provide any summary at the end of the lesson, indicates trained teachers are performing better. According to study findings of Sarker and Majumder ${ }^{20}$ in India, $65.3 \%$ of the students viewed that summarisation was not done by teacher at the end of a class which was much higher than the present study findings. About motivation towards selfdirected learning, $57.1 \%$ of the student agreed that teacher had motivated them properly for their self-learning with a mean score of $3.47 \pm 1.20$, which indicate it might be emphasized. Rahman ${ }^{10}$ found that $46.6 \%$ students were agreed and $39.65 \%$ disagreed to the statement that lectures helped them for their independent study. According to student's perception of building a self-directed learner Mayya and Roff ${ }^{22}$ in India found the mean score of $3.00 \pm$ 1.11 and $2.95 \pm 1.16$ between academic achiever and underachiever respectively, the score was below than that of the present study. Harden \& Laidlaw ${ }^{25}$ pointed out that the importance of self-directed learning has become increasingly recognised. Selfdirected learning does not mean that the teacher abandons the students to their own plans rather more appropriate term is 'directed selflearning'. Here students should be given more responsibility for their own learning and only need some form of support and direction from their teacher.

\section{Conclusion}

According to aggregated students' view, $38 \%$ of the teaching performances were excellent, $43 \%$ were good, $16 \%$ were satisfactory and $3 \%$ were unsatisfactory. It is assumed that training of the teacher plays crucial roles for good performances. To ensure excellence in teaching performances, a well-designed, updated and contextual training programme needs to be adopted. The findings of this study may provide insights for the teachers who want to improve the effectiveness of teaching for students' better learning. More rigorous and well designed further studies needed to overcome the limitations of this study. Along with CME, medical education unit (MEU) of the medical colleges may be encouraged to organize regular workshops to train up the teachers.

\section{References}

1. CANTRELL, T., 1973. How Do Medical-School Staff Learn To Teach? THE LANCET, 302, 724727.

2. World Health Organization, 1973. Postgraduate Education and Training in Public Health. World Health Organization Technical Repot Series No.533. World Health Organization, Geneva.

3. BARAL, N., GAUTAM, A., LAMSAL, M., PAUDEL,
B.H., LALDAS, B.K., ARYAL, M., 2011. Effectiveness of teachers' training in assessment techniques: participants' perception'. Kathmandu Univ med J, 35(3), 189-192.

4. JOSHI, S., PRADHAN, A., DIXIT, H., 2003. Faculty opinion survey following attendance to teacher training workshops in Kathmandu Medical College. Kathmandu University Medical Journal, 2(3), 244251.

5. http://www.gmc-uk.org/education/undergraduate/ tomorrows doctors 2009.asp retrieved on 10.09.2014.

6. STEINERT, Y., MANN, K., CENTENO, K., DOLMANS, D., SPENCER, J., GELULA, M., et al. 2006. A systematic review of faculty development initiatives designed to improve teaching effectiveness in medical education: BEME Guide No. 8. Medical Teacher, 28,(6), 497526.

7. NAGDEO, NV \& CHARI, S 2014, 'Basic Workshop for Medical Teachers: Effectiveness and Impact', NJIRM, 5 (2), 107-114.

8. TALUKDER, M.H.K, CHOWDHURY, F.P., RASHID, T.J., 2005. Evaluation of opinion on impact of teaching methodology workshop on teachers of different undergraduate and postgraduate medical institutes'. $J$. Med. Sci \& Res, 05(01), 13-18.

9. DENT, J., HARDEN, R. M., 2013. A practical guide for medical teachers. Elsevier Health Sciences.

10. RAHMAN, M.M., 2014. Assessing the role of medical teachers in managing teaching learning situation in the lecture classes of selected medical colleges. Thesis (MMEd). Bangabandhu Sheikh Mujib Medical University.

11. MOHAMMAD, S., MUAZZAM, N., HANIF, A., TALUKDER, H.K., HOSSAIN, M.Z., NAHAR, N., 2009. Large Group Teaching In the Medical Colleges of Dhaka City. J Dhaka Med Coll, 18(1), 28-32.

1. CANTRELL, T., 1973. How Do Medical-School Staff Learn To Teach? THE LANCET, 302, 724727.

2. World Health Organization, 1973. Postgraduate Education and Training in Public Health. World Health Organization Technical Repot Series No.533. World Health Organization, Geneva.

3. BARAL, N., GAUTAM, A., LAMSAL, M., PAUDEL, B.H., LALDAS, B.K., ARYAL, M., 2011. Effectiveness of teachers' training in assessment techniques: participants' perception'. Kathmandu Univ med J, 35(3), 189-192.

4. JOSHI, S., PRADHAN, A., DIXIT, H., 2003. Faculty opinion survey following attendance to teacher training workshops in Kathmandu Medical College. Kathmandu University Medical Journal, 2(3), 244251.

Bangladesh Journal of Medical Education 2016;7(1):14-19. 
5. http://www.gmc-uk.org/education/undergraduate/ tomorrows doctors 2009.aspretrieved on 10.09.2014.

6. STEINERT, Y., MANN, K., CENTENO, K., DOLMANS, D., SPENCER, J., GELULA, M., et al. 2006. A systematic review of faculty development initiatives designed to improve teaching effectiveness in medical education: BEME Guide No. 8. Medical Teacher, 28,(6), 497526.

7. NAGDEO, NV \& CHARI, S 2014, 'Basic Workshop for Medical Teachers: Effectiveness and Impact', NJIRM, 5 (2), 107-114.

8. TALUKDER, M.H.K, CHOWDHURY, F.P., RASHID, T.J., 2005. Evaluation of opinion on impact of teaching methodology workshop on teachers of different undergraduate and postgraduate medical institutes'. $J$. Med. Sci \& Res, 05(01), 13-18.

9. DENT, J., HARDEN, R. M., 2013. A practical guide for medical teachers. Elsevier Health Sciences.

10. RAHMAN, M.M., 2014. Assessing the role of medical teachers in managing teaching learning situation in the lecture classes of selected medical colleges. Thesis (MMEd). Bangabandhu Sheikh Mujib Medical University.

11. MOHAMMAD, S., MUAZZAM, N., HANIF, A., TALUKDER, H.K., HOSSAIN, M.Z., NAHAR, N., 2009. Large Group Teaching In the Medical Colleges of Dhaka City. J Dhaka Med Coll, 18(1), 28-32.

12. HUTCHINSON, L., 2003. ABC of learning and teaching Educational Environment. British Medical Journal, 12, 810-812.

13. NAHAR, N., TALUKDER, M. H. K., KHAN, M.T.H., MOHAMMAD, S., NARGIS, T., 2010. Students' Perception of Educational Environment of Medical Colleges in Bangladesh. BSMMUJ, 3(2), 97-102.

14. AL-NAGGAR, R.A., ABDULGHANI, M., OSMAN, M.T., AL-KUBAISY, W., DAHER, A.M., ARIPIN, K.N. et.al, 2014. The Malaysia DREEM: perceptions of medical students about the learning environment in a medical school in Malaysia. Advances in Medical Education and Practice, 5, 177-184.
15. YUSOFF, M.S.B., JA'AFAR, R., ARZUMAN, H., ARIFIN, W.N., MAT PA, M.N., 2013. Perceptions of medical students regarding educational climate at different phases of medical training in a Malaysian medical school. Education in Medicine Journal, 5(30), e30-e41.

16. GUILBERT, J.J., 1987. Educational Handbook for Health Personnel, $6^{\text {th }}$ edition, World Health Organization, Geneva.

17. AMIN, Z., ENG, K.H., 2003. Basics in Medical Education. National University of Singapore.

18. GULPINAR, M., YEGEN, B.C., 2005. Interactive Lecturing for Meaningful Learning in Large Groups. Medical Teacher, 27 (7), 590 594.19. MALIK, M.A., MURTAZA, D.A., KHAN, D.A.M., 2011. Role of Teachers in Managing Teaching Learning Situation. Interdisciplinary Journal of Contemporary Research in Business. 3(5), 783-821.

20. SARKAR, A.P., MAJUMDAR G., 2013. Perception on lecture class in Community Medicine among MBBS students of West Bengal in India. Reviews of Progress, $1(17), 1-7$.

21. MURTAZA, A., KHAN, A.M., KHAlEEQ, A.R., SAEED, S., 2012. An Evaluation of Classroom Management in Effective Teaching. International Journal of Business and Social Science, 3(3), 201-209.

22. MAYYA S.S., ROFF, S., 2004. Students' Perceptions of Educational Environment: A Comparison of Academic Achievers and Under-Achievers at Kasturba Medical College, India. Education for Health, 17 (3), 280291.

23. B.D, 2013. A Study On The Evaluation Of Perception Of Teaching-Learning Methods Of Pharmacology Among The 2nd M.B.B.S. Students In Burdwan Medical College, West Bengal, India. Reviews of Progress, 1(12), 1-11.

24. BENNAL, A., ITAGI, V., TAKLIKAR, R, 2014. Role of audio-visual aids in physiology lecture. Natl $J$ Physiol Pharm Pharmacol, 4 (2), 109-111.

25. HARDEN, R.M., LAIDLAW, J.M., 2012. ESSENTIAL SKILLS FOR A MEDICAL TEACHER. $1^{\text {st }}$ edition, Churchill Livingstone, Elsevier.

Bangladesh Journal of Medical Education 2016;7(1):14-19. 